\title{
Influence of Fertilizer, Aspect, and Harvest Date on Chemical Constituents and In Vitro Digestibility of Tall Fescue
}

\author{
G.E. PROBASCO AND A.J. BJUGSTAD
}

\begin{abstract}
The nutritional benefits of fertilization on Ozark forest range for the late spring and summer period are questionable. Fertilizer application did not enhance either protein or calcium content, but did increase phosphorus. Acid detergent fiber (ADF) increased on fertilized plots while in vitro dry matter digestibility (IVDMD) decreased. An interaction between harvest date and fertilizer treatment revealed higher IVDMD for fertilized plots in May, but the relation then reversed for the remainder of the study. Harvest date proved to be the most influential treatment in the study. The changes associated with harvest date reflect the normal phenological development of tall fescue. The forage becomes less nutritious and less digestible as it approaches maturity and dormancy in July and August. Aspect significantly influenced ADF content and IVDMD. ADF content was lower and IVDMD higher on southfacing slopes.
\end{abstract}

Fertilization of tall fescue (Festuca arundinacea Schreb.) on Ozark forest range increases production (Ehrenreich and Buttery 1960; Halls and Crawford 1963; and Crawford and Bjugstad 1967); but the influence on forage quality and digestibility is unknown. Pasture research on the same species or similar species in different areas has yielded considerable information on these factors. For example, Blaser (1964) noted increased carrying capacity under fertilization; however, individual animal output generally did not improve. He concluded that fertilization caused no appreciable difference in total digestible nutrients. Raymond (1969), in reviewing several papers on fertilizer and forage digestibility, drew a similar conclusion. Martz et al. (1967), working on orchardgrass in central Missouri, found results comparable to those of Blaser and Raymond. Kaiser (1971), during a 2-year study in southern Indiana, found no significant relationship between fertilizer application and in vitro dry matter digestibility in the first year of his study. During the second year, he found that fertilizer significantly increased IVDMD. Similar information is not available, but it is needed for large areas of the Ozarks in southern Missouri which are being converted to tall fescue grassland. This study was designed to measure the influence of fertilizer on the chemical constituents and digestibility of tall fescue. The effects of harvest date and aspect were also determined.

\section{Methods}

This study was conducted in the Ozark Plateau region of south-

Authors are, respectively, research wildlife biologist, North Central Forest Experiment Station, Forest Service, U.S. Department of Agriculture, Columbia, Missouri, and supervisory range scientist, Rocky Mountain Forest and Range Experiment Station, Forest Service, U.S. Department of Agriculture, Rapid City, South Dakota. Manuscript received September 5, 1978. ern Missouri. Over geologic time, the plateau has been eroded into numerous narrow winding valleys. Ridgetops range from 30 to 200 meters above valley bottoms. Soils are derived from dolomitic limestone and contain high percentages of cherty rock. Mineral nutrients and organic matter are low. Major soils are Clarksville (typic paleudult-loa my-skeletal, siliceous, mesic); Lebanon (typic fragiudalf-fine, mixed, mesic); and Nixa (glossic fragudultsloamy-skeletal, siliceous, mesic). The Ozarks receive about 90 to $100 \mathrm{~cm}$ annual precipitation, and have a growing season of approximately $180-200$ days.

The dominant vegetation is oak-hickory forest. Shortleaf pine occurs in the eastern Ozarks in either pure stands or mixed with oak, while redcedar becomes an important associated species in the western Ozarks. Hardwood quality is much better in the eastern Ozarks than in the western Ozarks. The lower quality hardwoods in the western Ozarks are the focal point for grassland conversion; primarily to pure stands of tall fescue. Some conversion does occur throughout the rest of the area.

Paired 0.2-ha plots were used for this study. One plot in each pair was topdressed in March with $54 \mathrm{~kg} / \mathrm{ha}$ each of NPK granulated fertilizer, while the other plot in each pair received no fertilizer. Plots were located on upper north- and south-facing slopes. Forage samples were collected during the first week of each month from May through November.

Leaves and stems were clipped to a 5-cm stubble, oven-dried, and ground, using a 2-mm screen to provide samples for chemical analysis and in vitro digestibility trials. Chemical analysis by the Agriculture Experiment Station Chemical Laboratories, University of Missouri, Columbia, Missouri, provided data on crude protein, calcium, phosphorus, and acid-detergent fiber. In vitro digestibility trials with cattle were determined by the Science and Education Administration, University of Missouri, using the twostage technique of Tilley and Terry (1963).

The experimental design was a three-factor factorial with two levels of application for each nutrient $\left(0\right.$ and $54 \mathrm{~kg} / \mathrm{ha} \mathrm{N}, \mathrm{P}_{2} \mathrm{O}_{5}$, $\mathrm{K}_{2} \mathrm{O}$ ), two aspects (north and south), two plots on each aspect, and seven harvest dates (May, June, July, August, September, October, and November). Statements of significance are based on standard analysis of variance $(P<.10)$ with significant effects being further subjected to Duncan's New Multiple Range Test $(P<$ .10).

\section{Results}

\section{Crude Protein}

Crude protein content was significantly related to harvest date. Crude protein contents decreased from $16.2 \%$ in May, a period of active spring growth, to only $8.1 \%$ in August, an inactive growth period (Table 1). By October growing conditions had improved and crude protein increased to $11.4 \%$. In November the plant material matured and crude protein content declined to $9.5 \%$. 
Table 1. Average protein, Ca, P, Ca:P, ADF, and IVDMD as affected by harvest date.

\begin{tabular}{lccccccc}
\hline \hline \multirow{2}{*}{$\begin{array}{l}\text { Item } \\
\text { measured }\end{array}$} & May & June & July & Aug. & Sept. & Oct. & Nov. \\
\cline { 2 - 8 } & Crude \\
Protein \% & $16.2 \mathrm{a}^{1}$ & $10.4 \mathrm{bc}$ & $9.1 \mathrm{~cd}$ & $8.1 \mathrm{~d}$ & $9.3 \mathrm{~cd}$ & $11.4 \mathrm{~b}$ & $9.5 \mathrm{~cd}$ \\
$\mathrm{Ca} \%$ & $.31 \mathrm{~d}$ & $.37 \mathrm{bc}$ & $.43 \mathrm{a}$ & $.41 \mathrm{ad}$ & $.36 \mathrm{c}$ & $.35 \mathrm{c}$ & $.29 \mathrm{~d}$ \\
$\mathrm{P} \%$ & $.29 \mathrm{a}$ & $.19 \mathrm{~cd}$ & $.21 \mathrm{bcd}$ & $.17 \mathrm{~d}$ & $.26 \mathrm{ab}$ & $.23 \mathrm{bc}$ & $.25 \mathrm{ab}$ \\
Ca:P & $1.13 \mathrm{~d}$ & $2.07 \mathrm{bc}$ & $2.31 \mathrm{~b}$ & $2.9 \mathrm{la}$ & $1.53 \mathrm{~cd}$ & $1.68 \mathrm{~cd}$ & $1.28 \mathrm{~d}$ \\
ADF $\%$ & $30.7 \mathrm{~d}$ & $34.8 \mathrm{bc}$ & $35.2 \mathrm{bc}$ & $35.8 \mathrm{~b}$ & $37.5 \mathrm{a}$ & $34.0 \mathrm{c}$ & $31.0 \mathrm{~d}$ \\
IVDMD \%68.2a & $59.6 \mathrm{c}$ & $58.4 \mathrm{~cd}$ & $57.0 \mathrm{~d}$ & $56.6 \mathrm{~d}$ & $62.2 \mathrm{~b}$ & $66.6 \mathrm{a}$ \\
\hline
\end{tabular}

'Means with the same letter on the same line are not significantly different-Duncan's Multiple Range Test $(P<.10)$.

${ }^{2} \mathrm{ADF}=$ Acid-detergent fiber; $\mathrm{IVDMD}=$ In vitro dry matter digestibility.

Crude protein content was also significantly related to aspect, although the differences were small; crude protein content for north- and south-facing slopes was 10.2 and $10.9 \%$, respectively (Table 2 ).

\section{Calcium}

Calcium content was significantly related to harvest date. Calcium content increased from $.31 \%$ in May to $.41 \%$ in August, and decreased to $.29 \%$ by November (Table 1). Calcium increased as plant material matured, then decreased as plants renewed growth in the fall.

\section{Phosphorus}

Phosphorus content was significantly related to both harvest date and fertilizer treatment. Harvest date effects exhibited a variable trend, increasing one month and decreasing the next (Table 1). Fertilizer treatment increased phosphorus content. Phosphorus content values were .18\% on unfertilized plots and $.28 \%$ on fertilized plots (Table 2).

\section{Calcium:phosphorus Ratio}

The Ca:P ratio was also significantly related to both harvest date and fertilizer treatment. Harvest date effects show $\mathrm{Ca}: \mathrm{P}$ increasing from 1.13 in May to 2.91 in August, then decreasing to 1.28 by November (Table 1). Fertilizer effects show the $\mathrm{Ca}: \mathrm{P}$ decreasing in response to fertilizer application. The respective values were 2.33 for unfertilized plots and 1.35 for fertilized plots (Table 2).

Table 2. Protein, $P, C a: P, A D F^{1}$, and IVDMD' $^{1}$ as affected by fertilizer treatment or aspect.

\begin{tabular}{lcclcc}
\hline \hline & \multicolumn{2}{c}{$\begin{array}{c}\text { Fertilizer treatment } \\
(\mathrm{kg} / \text { ha })\end{array}$} & & \multicolumn{2}{c}{ Aspect } \\
\cline { 2 - 3 } \cline { 5 - 6 } Item measured & 0 & 55 & & North & South \\
\hline Crude protein $\%$ & 10.5 & $10.6 \mathrm{NS}$ & 10.2 & 10.9 \\
Ca $\%$ & .37 & $.35 \mathrm{NS}$ & .36 & $.36 \mathrm{NS}$ \\
Phosphorus $\%$ & .18 & .28 & & .23 & $.23 \mathrm{NS}$ \\
Ca:P & 2.33 & 1.35 & & 1.9 & $1.8 \mathrm{NS}$ \\
ADF \% & 33.7 & 34.6 & & 34.7 & 33.6 \\
IVDMD \% & 62.7 & 59.7 & & 60.6 & 61.8 \\
\hline
\end{tabular}

ADF = Acid-detergent fiber; IVDMD = In vitro dry matter digestibility; NS = Nonsignificant.

\section{Acid-detergent Fiber}

ADF was significantly related to harvest date, fertilizer treatment and aspect. ADF varied over the harvest period from 30.7 in May to $37.5 \%$ in September, and back to $31 \%$ by November (Table 1). Fertilizer treatment increased ADF from $33.7 \%$ on unfertilized plots to $34.6 \%$ on fertilized plots (Table 2). Aspect effects showed ADF to be higher for north-facing slopes than for south-facing slopes. The respective values were 34.7 and 33.6 (Table 2).

\section{In Vitro Dry Matter Digestibility}

IVDMD responded significantly to harvest date, fertilizer treatment, aspect, and interaction between harvest date and fertilizer treatment. IVDMD decreased from $68.2 \%$ in May to $56.6 \%$ in September; then increased to $66.2 \%$ for the November regrowth (Table 1).

The response of fertilizer treatment showed significantly higher IVDMD values for unfertilized plots over the fertilized plots. The respective IVDMD values were $62.7 \%$ and $59.7 \%$ (Table 2).

The harvest date-fertilizer treatment interaction occurred during the interval between May and June harvest dates. IVDMD values for fertilized and unfertilized plots were $69.1 \%$ and $67.2 \%$, respectively, in May; but the relation changed to $58.5 \%$ and $60.8 \%$, respectively, in June and remained in that position throughout the rest of the growing season.

The response to aspect revealed significantly higher IVDMD values for south-facing slopes than for northfacing slopes. The IVDMD values were 61.8 and 60.6 , respectively.

\section{Discussion}

Our results show that tall fescue grown on Ozark forestrange provides higher quality forage both early and late in the growing season, with a significant drop in quality during the summer when tall fescue is dormant or nearly so. Harvest date proved to be the most influential variable in this study. Fertilizer treatment proved not to be the influential factor that we had anticipated it might be, or at least not in the manner that we had expected. Aspect is generally considered important because of the rough Ozark topography; however, significant differences in crude protein, ADF, and IVDMD due to aspect are probably inconsequential from a management standpoint and do not merit further discussion.

The influence of harvest date is manifest through the normal seasonal growth cycle of cool-season grasses such as tall fescue. As the grass approaches maturity at the end of the spring growing season, quality drops considerably; however, it will begin to improve once fall regrowth begins. It was anticipated that fertilizer might overcome some of this quality loss; however, this was not the case, and in some instances fertilizer apparently depressed the forage quality. Fertilizer may be important in keeping the $\mathrm{Ca}: \mathrm{P}$ ratio within the optimum range of .5 to 2.0 . While phosphorus content and $\mathrm{Ca}: \mathrm{P}$ ratio responses were expected with phosphorus being added in the fertilizer, ADF and IVDMD responses were not.

It appears that the main response to fertilizer is increased fiber production. Although we realize that portions of ADF are digestible, this is usually not a large amount and we feel that the increase in ADF indicates lessened digestibility. Our IVDMD data lend support for this assumption, as it decreased on fertilized plots. What this means is that the increased production from fertilization must be weighed against the lowered digestibility when evaluating the benefits of fertilizer. If production increases are substantial enough to offset decreased digestibility so that there is actually an increase in digestible forage, then fertilization may pay. The harvest date-fertilizer treatment interaction that 
occurred in the IVDMD data suggests that the additional fiber is produced during the time toward the end of the spring growing period.

\section{Literature Cited}

Blaser, R.E. 1964. Symposium on forage utilization: Effects of fertility levels and stages of maturity on forage nutritive value. J. Anim. Sci. 23: 246-253.

Crawford, H.S., and A.J. Bjugstad. 1967. Establishing grass range in the southwest Missouri Ozarks. U.S. Dep. Agr., Forest Serv., Res. Note NC22, 4 p. North Cen. Forest Exp. Sta., Columbia, Mo.
Ehrenreich, J.H., and R.F. Buttery. 1960. Increasing forage on Ozark wooded ranges. U.S. Dep. Agr., Forest Serv., Tech. Pap. CS-177, 10 p., Cen. States Forest Exp. Sta.

Halls, L.K., and H.S. Crawford. 1963. Vegetation response to an Ozark woodland spraying. J. Range Manage., 18: 338-340.

Kaiser, C.J. 1971. Isolation of factors influencing the utilization of (Festuca arundinacea Schreb.) by ruminants during the grazing season. Ph.D. Diss., Univ. Missouri, Columbia, 260 p.

Martz, F.A., J.R. Brown, B.K. Dar, and D.D. Pagitt. 1967. Effect of topdressed nitrogen and potassium in the feeding values of orchardgrass hay for lactating dairy cows. Agron. J., 59: 599-602.

Tilley, J.M.A., and R.A. Terry. 1963. A two-stage technique for the in vitro digestion of forage crops. J. British Grassland Soc. 18: 104-111. 